\title{
A Test System for Tick-Borne Encephalitis Virus Detection Based on Bioluminescent Immunoassay
}

\author{
Alexander N. Kudryavtsev ${ }^{\mathrm{a}}$, Ludmila P. Burakova ${ }^{\mathrm{a}, \mathrm{b}}$, \\ Ksenia A. Barinova ${ }^{b}$ and Ludmila A. Frank*a,b \\ ${ }^{a}$ Institute of Biophysics SB RAS \\ FRC "Krasnoyarsk Science Center SB RAS" \\ Krasnoyarsk, Russian Federation \\ ${ }^{b}$ Siberian Federal University \\ Krasnoyarsk, Russian Federation
}

Received 23.04.2018, received in revised form 20.06.2018, accepted 25.06.2018, published online 03.06.2019

\begin{abstract}
The tick-borne encephalitis virus (TBEV) is the causative agent of one of the most severe human neuroinfections. The infection transmitted by ixodid ticks is spread throughout the forest and forest-steppe zones of the temperate climatic belt of the Eurasian continent, including the Siberian region of the Russian Federation. Despite the availability of commercial analytical systems for the detection of TBEV, the task of developing approaches to a quick and reliable analysis that can be performed routinely, particularly in environmental studies, remains topical. A solid-phase bioluminescent immunoassay for determining the tick-borne encephalitis virus (TBEV) in ticks was developed. The assay is based on the hybrid protein consisting of a modified thermostable version of Renilla muelleri luciferase and a single-chain mini-antibody to protein $\mathrm{E}$. This unique protein had been obtained and investigated by the authors earlier. The current study describes the expression of the hybrid protein in two different strains of recombinant $E$. coli cells. The optimal conditions for obtaining a highly purified protein were found. The bioluminescent reaction of the luciferase domain was triggered with the help of the stable natural form of the substrate, a $\mathrm{Ca}^{2+}$-dependent coelenterazine-binding protein, the recombinant variant of which was obtained by the authors. The conditions for production and storage of the immunoassay components (the hybrid protein, the stable form of the luciferase substrate, and activated microplates) were determined. Using the developed test system, more than 900 tick samples were analyzed for TBEV. In terms of sensitivity (89.5\%) and specificity $(98.9 \%)$, the proposed method is not inferior to colorimetric detection and is much simpler and faster than the latter.
\end{abstract}

(C) Siberian Federal University. All rights reserved

This work is licensed under a Creative Commons Attribution-NonCommercial 4.0 International License (CC BY-NC 4.0).

* Corresponding author E-mail address: 1frank@yandex.ru 
Keywords: tick-borne encephalitis virus (TBEV), bioluminescent microassay, hybrid protein 14D5aRm7.

Citation: Kudryavtsev A.N., Burakova L.P., Barinova K.A., Frank L.A. A test system for tick-borne encephalitis virus detection based on bioluminescent immunoassay. J. Sib. Fed. Univ. Biol., 2020, 13(3), 310-321. DOI: 10.17516/1997-1389-0296

\title{
Тест-система для выявления \\ вируса клещевого энцефалита \\ биолюминесцентным иммуноанализом
}

\author{
А.Н. Кудрявцева ${ }^{\text {, Л.П. Буракова }}{ }^{\text {a, }}$, \\ К.А. Баринова ${ }^{\tilde{\sigma}}$, Л.А. Франк ${ }^{\mathrm{a}, \boldsymbol{\sigma}}$ \\ ${ }^{a}$ Институт биофизики СО РАН \\ ФИЦ «Красноярский научный изентр СО РАН» \\ Российская Федераџия, Красноярск \\ ${ }^{\sigma}$ Сибирский федеральный университет \\ Российская Федераџия, Красноярск
}

\begin{abstract}
Аннотация. Вирус клещевого энцефалита (ВКЭ) является инфекционным агентом тяжелого нейрозаболевания - клещевого энцефалита. Он переносится иксодовыми клещами, инфекция распространена по всей лесной и лесостепной зоне умеренного пояса Евразийского континента, в том числе в Сибирском регионе Российской Федерации. Несмотря на наличие коммерческих аналитических систем для выявления ВКЭ, задача разработки быстрых и достоверных методов анализа, пригодных для рутинного применения, в том числе и при экологических исследованиях, остается актуальной. В результате проведенных исследований разработана и испытана тест-система для выявления вируса клещевого энцефалита (ВКЭ) в клещах твердофазным биолюминесцентным иммуноанализом. В качестве сенсора использовали гибридный белок, состоящий из одноцепочечного мини-антитела мыши к вирионному белку Е и термостабильного варианта люциферазы Renilla muelleri. Этот уникальный белок был получен и исследован авторами ранее. В работе рассмотрены варианты экспрессии гибрида рекомбинантными клетками E. coli разных штаммов и найдены оптимальные условия получения высокоочищенного препарата этого белка. Запуск биолюминесцентной реакции люциферазного домена осуществляли с помощью стабильной природной формы субстрата $-\mathrm{Ca}^{2+}$-зависимого целентеразин-связывающего белка, рекомбинантый вариант которого был получен авторами ранее. Найдены условия долгосрочного хранения ключевых элементов системы - гибридного белка, стабильной формы субстрата люциферазы, активированных планшетов. Анализ осуществляется в высокопроизводительном микропланшетном варианте. Разработанным способом исследовано более 900 образцов природных клещей. По чувствительности $(89,5$ \%) и специфичности $(98,9$ \%) биолюминесцентный анализ не уступает колориметрическому, будучи при этом проще и быстрее.
\end{abstract}


Ключевые слова: вирус клещевого энцефалита (ВКЭ), биолюминесцентный иммуноанализ, гибридный белок 14D5a-Rm7.

Цитирование: Кудрявцев, А.Н. Тест-система для выявления вируса клещевого энцефалита биолюминесцентным иммуноанализом / А.Н. Кудрявцев, Л.П. Буракова, К.А. Баринова, Л.А. Франк // Журн. Сиб. федер. ун-та. Биология, 2020. 13(3). C. 310-321. DOI: 10.17516/1997-1389-0296

\section{Введение}

Вирус клещевого энцефалита (ВКЭ) является инфекционным агентом тяжелейшего нейрозаболевания - клещевого энцефалита. Он переносится иксодовыми клещами, ареал распространения которых вся лесная и лесостепная зона умеренного пояса Евразийского континента, в том числе Сибирский регион Российской Федерации, Китай и Монголия (Süss, 2011). Современная эпидемическая ситуация в отношении клещевого энцефалита характеризуется значительным ростом заболеваемости как в России, так и в мире (Lenhard et al., 2016). Экстренная профилактика клещевого энцефалита у невакцинированных укушенных пациентов включает введение препарата иммуноглобулина человека против клещевого энцефалита, полученного из сыворотки донорской крови. Применение продуктов донорской крови всегда сопровождается биологическим риском. Вместе с тем показано, что в среднем носителями вируса клещевого энцефалита являются лишь 5-10 \% клещей. Поэтому быстрое, высокочувствительное выявление его наличия или отсутствия необходимо во избежание необоснованного применения иммунопрофилактики и, как следствие, для снижения количества случаев возможных осложнений.

Несмотря на наличие коммерческих аналитических систем для выявления ВКЭ колориметрическим иммуноанализом или на основе ПЦР с обратной транскрипцией (ОТПЦР), известными производителями которых в России являются биотехнологические компании «Вектор-Бест» и «Микроген», задача разработки подходов, обеспечивающих быстрый и достоверный анализ, пригодный для рутинного применения, в том числе и при экологических исследованиях, остается актуальной.

Недавно нами был предложен способ выявления ВКЭ на основе биолюминесцентного твердофазного иммуноанализа. Ключевым элементом способа выступает гибридный белок 14D5a-Rm7 (Burakova et al., 2015; Патент РФ, 2014), включающий люциферазу мягкого коралла Renilla muelleri (Rm7, генетически модифицированный термостабильный вариaнт, Stepanyuk et al., 2010) и одноцепочечное мини-антитело мыши 14D5a против поверхностного вирионного белка E (Tsekhanovskaya et al., 1993; Байков и др., 2012). Эксперименты с модельными объектами (белком Е и лабораторными клещами) показали, что с помощью этого репортера возможно выявлять до $10^{4}-10^{5}$ вирусных частиц или 0,1 пг (Burakova et al., 2015). Это превосходит возможности колориметрического иммуноанализа и сопоставимо с анализом на основе ОТ-ПЦР.

В качестве субстрата люциферазного домена исследован целентеразин, а также его природная форма в виде целентеразина, «упакованного» в полости $\mathrm{Ca}^{2+}$-зависимого целентеразин-связывающего белка (СВР) (Titushin et al., 2008). Показано, что последний взаимодействует с доменом люциферазы более эффективно (Kudryavtsev et al., 2017).

Целью данной работы была разработка быстрой и чувствительной биолюминесцент- 
ной тест-системы по выявлению ВКЭ и демонстрация ее пригодности для анализа природных клещей.

\section{Материалы и методы}

Материаль

Целентеразин (CE) получен от Prolume Ltd. (Pinetop, США). Все вспомогательные реагенты (соли, кислоты, щелочи, органические растворители) были аналитической или химической чистоты.

Экстракты природных клещей были получены из Центра гигиены и эпидемиологии Красноярского края. Около 5 \% исследованных образцов экстрактов было приготовлено из целых клещей самостоятельно, по методу, описанному для набора D-1154 (Вектор Бест, Россия). ВКЭ в клещах выявляли колориметрическим иммуноанализом с использованием «Набора реагентов для иммуноферментного выявления антигена вируса клещевого энцефалита D-1154» (Вектор Бест, Россия) в соответствии с протоколом производителя.

\section{Получение гибридного белка 14D5a-Rm7}

A) Клетки E. coli BL21 CodonPlus (DE3) RIPL (Stratagene, США), трансформированные плазмидой pFLAG-ompA-14D5a-Rm7, культивировали при активном перемешивании в LB среде, содержащей 200 мкг/мл ампициллина, при $37{ }^{\circ} \mathrm{C}$. При оптической плотности культуры ОД 590 0,6-0,7 ее охлаждали до $23{ }^{\circ} \mathrm{C}$, вносили 0,5 мМ изопропил- $\beta$ D-1-тиогалактопиранозида (ИПТГ; Диа-М, Россия) и продолжали культивирование при $23{ }^{\circ} \mathrm{C}$ в течение 20 ч. Клетки отделяли центрифугированием, из них выделяли периплазматическую фракцию, из которой очищали целевой белок хроматографией на колонке HisTrap Ni-NTA Agarose (QIAgen, Germany), уравновешенной 50 мМ K-Na фосфатным буфером (ФБ) $\mathrm{pH}=7,0$, линейным градиентом имидазола (10-200 мМ) в том же буфере. Фракции, содержащие целевой белок (определяли по биолюминесцентной активности), объединяли.

Выделение целевого белка из периплазмы клеток E. coli HB2151 (Stratagene, США), трансформированных данной плазмидой, проводили аналогично.

Б) Клетки E. coli Rosetta-gami 2 (Novagen, США), трансформированные плазмидой pFLAG-14D5a-Rm7 (Патент РФ, 2014), культивировали, как описано выше. Клетки осаждали центрифугированием, суспендировали в буфере А (5 мМ имидазол, $0,3 \mathrm{M} \mathrm{NaCl}$, 20 мM Tris-HCl pH 7,0) и дезинтегрировали ультразвуком при охлаждении льдом. Смесь центрифугировали, супернатант наносили на колонку HisTrapTM HP (GE Healthcare), уравновешенную буфером А, и элюировали вещества с колонки линейным градиентом имидазола (50-200 мМ) в том же буфере. Фракции, содержащие целевой белок, объединяли, концентрировали и наносили на колонку Superdex 75 (GE Healthcare), уравновешенную 20 мM Tris-HCl pH 7,0, содержащим 0,5 мМ ЭДТА и $25 \mathrm{MM} \mathrm{NaCl,} \mathrm{элюировали} \mathrm{этим}$ же раствором. Фракции, содержащие целевой белок, объединяли.

\section{Получение}

целентеразин-связывающего белка

Целентеразин-связывающий белок (CBP) получали, как описано ранее (Titushin et al., 2008). Кратко: клетки E. coli BL21 (DE3) Codon Plus (RIPL), трансформированные плазмидой с геном апо-СВР, культивировали в условиях, описанных выше. При оптической плотности культуры ОД 590 0,6-0,7 вносили 1 мМ ИПТГ и культивировали в тех же условиях 3 ч. Клетки осаждали, суспендировали в 20 мM Tris-HCl pH 7,0 и дезинтегриро- 
вали ультразвуком при охлаждении льдом. Смесь центрифугировали, осадок растворяли в 6 М мочевине, наносили на колонку DEAE-Sepharose FF, уравновешенную $6 \mathrm{M}$ мочевиной в 20 мМ Tris- $\mathrm{HCl}$ рH 7,0, и хроматографировали в градиенте ацетата аммония (0-0,3 М) в том же буфере. Образец, содержащий апо-СВР, разводили десятикратным объемом раствора целентеразина (1,2-молярный избыток) в 20 мM Tris- $\mathrm{HCl}$ pH 7,0, 5 мM ЭДТА и инкубировали при $8{ }^{\circ} \mathrm{C}$ в течение ночи. Целевой белок СВР очищали хроматографией на колонке Mono-Q (GE Healthcare), уравновешенной 20 мM Tris- $\mathrm{HCl} \mathrm{pH}$ 7,0, 5 мМ ЭДТА в градиенте $\mathrm{NaCl}(0-0,35$ M). Типичный выход высокоочищенного СВР coставлял 30-35 мг на литр культуры.

\section{Измерение биолюминесцентного сигнала}

Биолюминесцентный сигнал измеряли при быстром смешивании: а) 5 мкл свежеприготовленного раствора целентеразина (от 1,32 до 660 мМ в этаноле) с 500 мкл раствора 14D5a-Rm7 (13,3 нM в 50 мM Tris- $\mathrm{HCl}$ pH 7,0, 25 мМ NaCl, 0,5 мМ ЭДТА); б) 5 мкл раствоpa CBP (от 0,15 до $150 \mathrm{мM} \mathrm{в} 20 \mathrm{mM}$ Tris-HCl pH 7,0, 25 мМ NaCl, 0,5 мМ ЭДТА) с 500 мкл раствора 14D5a-Rm7 (1,5 нM в 50 мM Tris-HCl $\mathrm{pH}$ 7,0, 25 мM NaCl, 10 мМ CaCl 2 ). Измерения проводили при $20{ }^{\circ} \mathrm{C}$ в термостатированной кювете люминометра БЛМ 8802 (СКТБ Наука, Красноярск). Все измерения проводили не менее чем в трех повторностях.

\section{Приготовление и хранение}

\section{активированных микропланиетов}

В лунки непрозрачного микропланшета (Corning, США) вносили по 100 мкл раствора мышиных моноклональных антител 14D5 (Биосан, Россия), 5 мкг/мл в 50 мМ K-Na фосфатном буфере $\mathrm{pH} 7,0$, содержащем 0,15 M $\mathrm{NaCl}$ (ФСБ), инкубировали ночь при $8^{\circ} \mathrm{C}$, про- мывали (ФСБ, содержащий 0,1% Tween 20) и блокировали свободную поверхность лунки инкубированием со 150 мкл 1\%-го раствора поливинилпирролидона в ФСБ в течение 1 ч при $37^{\circ} \mathrm{C}$. Далее планшет промывали, сушили на воздухе, покрывали клейкой пленкой и хранили при температуре 8 или минус $18^{\circ} \mathrm{C}$.

\section{Биолюминесиентный}

микроанализ экстрактов клещей

В лунки активированного планшета вносили по 100 мкл экстрактов клещей, позитивного $(\mathrm{K}+)$ или негативного (К-) контролей из набора D-1154 (Вектор Бест, Россия) и инкубировали 1 ч при $37{ }^{\circ} \mathrm{C}$ при встряхивании. После промывки вносили раствор 14D5a-Rm7 (по 100 мкл, 1 мкг/мл в ФСБ), инкубировали 1 ч при $23^{\circ} \mathrm{C}$, затем тщательно промывали. Биолюминесценцию связавшегося 14D5a-Rm7 измеряли с помощью планшетного люминометра LB 940 Mithras (Berthold, Германия) сразу после впрыска 100 мкл раствора СВР (1,5 мкМ, 100 мМ $\mathrm{CaCl}_{2}$ в Tris- $\left.\mathrm{HCl} \mathrm{pH} 7,0\right)$.

\section{Приготовление}

и хранение лиофилизированных образияов CBP и 14D5a-Rm7

Растворы белков в ФСБ (СВР - 2,5 мг/мл, 14D5a-Rm7 - 0,5 мг/мл), а также в ФСБ, содержащем: 5 \% трегалозы, 0,1 \% либо $1 \%$ бычьего сывороточного альбумина (БСА, Sigma-Aldrich, США), быстро замораживали при минус $80{ }^{\circ} \mathrm{C}$ и лиофилизовали в камере BenchTop Pro (SP 85 Scientific, США). Полученные образцы хранили в камере бытового холодильника (около $8{ }^{\circ} \mathrm{C}$ ) и периодически проверяли их в модельном иммуноанализе с использованием образцов К+ (Вектор Бест, Россия) в качестве антигена. Для сравнения тот же анализ проводили параллельно с использованием свежеприготовленных белков. 


\section{Результаты и обсуждение}

Разработка тест-системы включала: получение наиболее оптимальным способом гибридного белка, обладающего функциями родительских белков; разработку стабильного субстрата люциферазного домена; поиск условий хранения ключевых белковых элементов анализа, а также активированных микропланшетов; экспериментальное подтверждение пригодности разрабатываемой системы для выявления ВКЭ в природных клещах.
Получение и свойства гибридного белка

В состав гибридного сенсорного белка входят: распознающий элемент - одноцепочечное мини-антитело мыши 14D5a против белка Е ВКЭ, состоящее из вариабельных доменов тяжелой и легкой цепей $\left(\mathrm{V}_{\mathrm{H}}\right.$ и $\left.\mathrm{V}_{\mathrm{L}}\right)$, соединенных гибким линкером, и сигнальный элемент - термостабильный вариант люциферазы мягкого коралла Renilla muelleri (Rm7), способный генерировать световой сигнал при добавлении субстрата - целентеразина (рис. $1 A$ ). Домен мини-антитела присоединен

\section{A) sc14D5a

\begin{tabular}{|l|l|l|}
\hline$V_{H 14 D 5} \sim V_{L 14 D 5 a}$ & $R m 7$ & $H_{6}$ \\
\hline
\end{tabular}

Б)

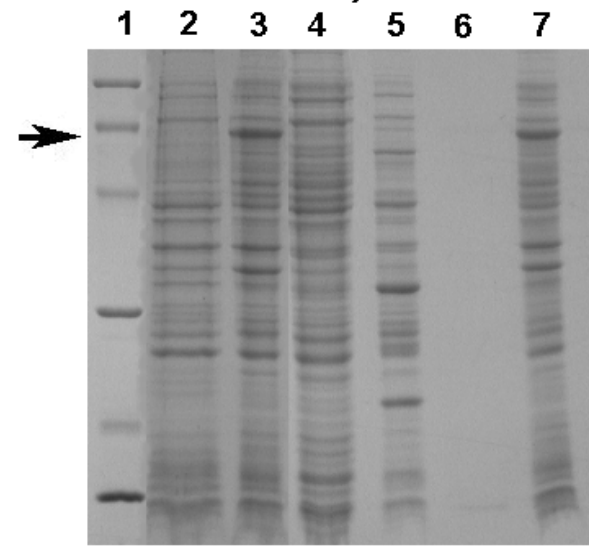

B)

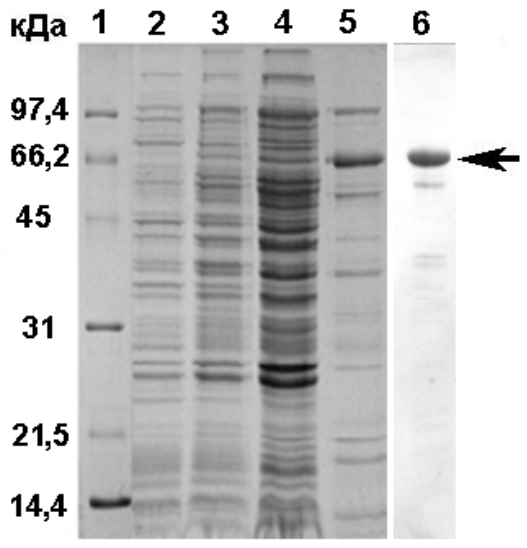

Рис. 1. А) Домены в составе гибридного белка. Б) Электрофоретический анализ образцов, полученных при выделении гибридного белка 14D5a-Rm7 из клеток E. coli штамм BL21 Codon Plus (DE3) RIPL; 1 - стандартные белки; 2, 3 - лизат клеток до и после индукции; 4 - цитоплазматическая фракция; 5 - периплазматическая фракция, сконцентрированная в 10 раз; 6 -препарат после очистки изпериплазмы; 7-экстракттелец включения в 6 М мочевину. В) Электрофоретический анализ образцов при выделении гибридного белка из клеток E. coli Rosetta-gami 2: 1-4 - то же, что и для случая (Б); 5, 6 - препараты после первой и второй хроматографий. Молекулярная масса стандартных белков (Amersham Bioscience) показана числами. Электрофорез проводили в 12,5\%-м полиакриламидном геле в денатурирующих условиях, окрашивание Coomassie blue. Стрелками показана полоса гибридного белка

Fig. 1. A) Hybrid protein domains. Б) SDS-PAGE analysis of 14D5a-Rm7-containing-protein fractions during purification of the sample obtained from E. coli, strain BL21 Codon Plus (DE3) RIPL. Lanes: 1 - standard proteins; 2 and 3, whole-cell lysates before and after IPTG induction respectively; 4 - cytoplasm; 5 - periplasmic fraction (concentrated 10-fold); 6-sample from periplasmic fraction after purification; 7-6 M urea extract of inclusion bodies; B) SDS-PAGE analysis of 14D5a-Rm7- containing protein fractions during purification of the sample obtained from E. coli Rosetta-gami 2. Lanes: 1-4 - the same samples like in case (Б); 5, 6-samples after metal affinity chromatography and gel-filtrations, correspondingly. Molecular masses of standard proteins (Amersham Bioscience) are shown with numbers. $12.5 \%$ polyacrylamide gels stained with Coomassie blue. Arrows show the band corresponding to the hybrid protein 
к люциферазе с $N$-конца через линкер $(\mathrm{GGC})_{4}$, a с $C$-конца люциферазы присоединен гексагистидиновый пептид $\mathrm{H}_{6}$ для выделения целевого гибрида с помощью металл-аффинной хроматографии.

Для получения с помощью бактериальной экспрессии бифункционального гибридного белка, проявляющего свойства обоих входящих в его состав доменов, были рассмотрены два варианта с локализацией: (а) в периплазматическом пространстве клеток E. coli, для чего ген целевого белка включал последовательность, кодирующую лидерный пептид ompA; (б) в цитоплазме клеток E. coli Rosettagami 2, содержащих мутированные гены тиоредоксин редуктазы и глутатион редуктазы, в результате чего существенно активируется образование дисульфидных связей в белках. На рис. $1 Б, B$ приведен анализ фракций при получении и очистке гибридного белка. В обоих случаях добавление ИПТГ инициирует синтез целевого гибрида: на электрофореграммах появляется полоса с молекулярной массой, близкой к расчетному значению 65,5 кДа. Видно, что количество белка, выделяемое из периплазматического пространства клеток E. coli BL21 (рис. 1Б), чрезвычайно мало, его присутствие контролировали по биолюминесцентной активности люциферазного домена. После хроматографической очистки выход белка составил 0,02-0,025 мг на литр культуры. Как видно из данных электрофореграммы, значительное количество белка локализовано в виде телец включения. К сожалению, после растворения 6 М мочевиной с последующей заменой буфера гибрид не обладает биолюминесцентной активностью. Попытки увеличить выход целевого белка в периплазматическом пространстве клеток E. coli штаммов TG1, HB2151 и DH5 $\alpha$ не привели к желаемому результату (данные не приводятся). Можно предположить, что перенос гибридного белка в периплазму затруднен изза его высокой молекулярной массы или специфической пространственной структуры.

Рисунок $1 B$ демонстрирует, что при синтезе гибрида в клетках E. coli Rosetta-gami 2 практически весь гибридный белок сосредоточен в цитоплазматической фракции, где его количество составляет $0,9 \%$ от всех цитоплазматических белков. В результате двух хроматографий получали препарат целевого белка 87\%-й чистоты с выходом 2-3 мг на литр культуры, обладающего биолюминесцентной активностью при добавлении целентеразина.

\section{Каталитические свойства}

домена люииферазы

Биолюминесценция Renilla возникает в результате реакции окисления целентеразина кислородом, катализируемой люциферазой, с образованием целентерамида, $\mathrm{CO}_{2}$ и кванта света $\left(\lambda_{\max }=480\right.$ нм). В фотофорах животного это соединение иммобилизовано во внутренней полости $\mathrm{Ca}^{2+}$-активируемого целентеразин-связывающего белка (СВP) (Titushin et al., 2008). Присоединение ионов $\mathrm{Ca}^{2+}$ вызывает конформационные изменения молекулы, в результате которых целентеразин становится доступным для окисления, катализируемого люциферазой (Stepanyuk et al., 2009).

Применение целентеразина в системах in vitro сопровождается рядом неудобств: он является гидрофобным соединением, плохо растворимым в водных средах. Поскольку это соединение довольно быстро самопроизвольно окисляется, необходимо использовать только свежеприготовленные растворы. В то же время СВР - стабильный, хорошо растворимый белок, представляет собой более удобную для рутинного использования форму субстрата. Нами были рассмотрены каталитические свойства домена люциферазы при 
взаимодействии с обеими формами субстрата (рис. 2). В табл. 1 приведены значения кинетических параметров этих реакций: константы Михаэлиса (Км), максимальная скорость реакции (Vmax). Необходимо заметить, что биолюминесцентная реакция люциферазы протекает с определенным квантовым выходом и потому полученные по биолюминесценции значения кинетических параметров следует считать кажущимися (термин, который мы далее опускаем).

Можно видеть, что значение Kcat, отражающее число оборотов фермента в едини- цу времени, а также параметр Ксаt/Км для случая СВР существенно выше, чем для свободного целентеразина, что свидетельствует в пользу более высокой эффективности биолюминесцентной реакции. Аналогичные результаты были получены при исследовании каталитических свойств свободной люциферазы Renilla muelleri с этими формами субстрата (Titushin et al., 2008). Было показано, что присоединение ионов $\mathrm{Ca}^{2+}$ вызывает конформационные изменения белка с разрушением сети водородных связей, участвующих в иммобилизации целентеразина, делая его
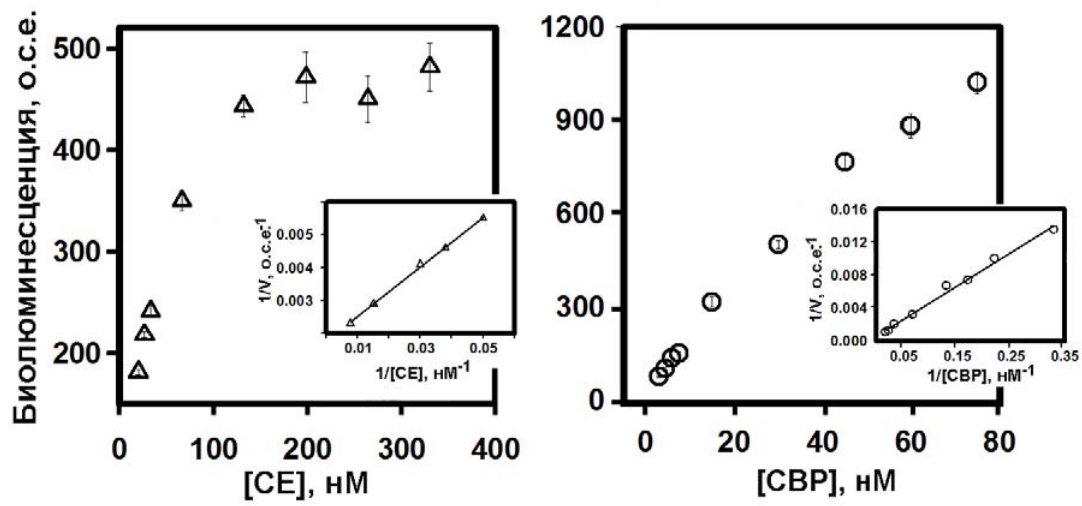

Рис. 2. Зависимость биолюминесцентного сигнала 14D5a-Rm7 от концентрации целентеразина (слева) и CBP (справа). Каждая точка - среднее от трех измерений начальной (максимальной) интенсивности сигнала. На врезках - графики Лайнуивера-Берка. о.с.е. - относительные световые единицы

Fig. 2. 14D5a-Rm7 bioluminescence vs. coelenterazine (left) and CBP (right) concentration. Each point is the average of the initial (maximal) bioluminescence intensity \pm standard deviation, $n=3$. Inset: Lineweaver-Burk plots. r.l.u. - relative light units

Таблица 1. Кинетические параметры биолюминесцентной реакции 14D5a-Rm7 с разными формами субстрата

Table 1. Kinetic parameters of the 14D5a-Rm7 bioluminescent reaction with two substrate types

\begin{tabular}{|c|c|c|}
\hline Параметр & CE & CBP \\
\hline Км $(\text { мкM) })^{1}$ & 0,91 & 0,43 \\
\hline $\operatorname{Vmax}(\text { о.c.e. })^{2}$ & 588 & 1094 \\
\hline Kcat $\left(\mathrm{c}^{-1}\right)$ & 44,54 & 729 \\
\hline Kcat $/$ Км $\left(\right.$ мкM с $\left.{ }^{-1}\right)$ & 48,95 & 1696 \\
\hline
\end{tabular}

${ }^{1} 10^{-6} \mathrm{M}$;

${ }^{2}$ относительные световые единицы. 
доступным для окисления. Наблюдаемое увеличение эффективности биолюминесцентной реакции с высокой долей вероятности объясняется образованием короткоживущего комплекса «люцифераза - $\mathrm{Ca}^{2+}$-активированный CBP» (Stepanyuk et al., 2009). Таким образом, использование СВР как субстрата в разрабатываемой тест-системе дает очевидные преимущества по сравнению со «свободным» целентеразином. Рекомбинантный СВР доступен благодаря наличию бактериального штамма-суперпродуцента апобелка, а также разработанному простому способу его получения.

Аффинные свойства полученного гибрида проверяли с помощью твердофазного биолюминесцентного анализа рекомбинантного белка Е ВКЭ (Burakova et al., 2015). Полученное для гибридного белка значение константы аффинности Kaff $=2,65 \times 10^{7} \mathrm{M}^{-1}$ близко таковому для немодифицированного рекомбинантного антитела мыши sc14D5a 1,6× $10^{7} \mathrm{M}^{-1}$ (Baykov et al., 2009).

Таким образом, синтез в клетках E. coli Rosetta-gami 2 обеспечивает хороший выход гибрида, домены которого обладают биоспецифическими свойствами исходных белков.

\section{Стабильность 14D5a-Rm7 и CBP}

при хранении в лиофилизированном виде

Нами обнаружено, что образцы, лиофилизированные из фосфатно-солевого буфера, необратимо теряют до 80 \% биолюминесцентной активности. Добавление к раствору трегалозы либо бычьего сывороточного альбумина существенно увеличивает стабильность белков при лиофильной сушке. Показано, что биолюминесцентная активность 14D5a-Rm7, лиофилизированного в присутствии 0,1% БСА, практически не изменялась через сутки, 4 месяца и год и составляла $86,5 \pm 0,7,85,1 \pm 1,6$ и $88,3 \pm 1,2 \%, n=4$, от активности свежевыде- ленного образца соответственно. Биолюминесцентные сигналы при запуске добавлением лиофилизированного в тех же условиях препарата СВР через сутки, 4 месяца и год хранения практически не изменялись: их интенсивность составляла 98 $\pm 4,5,93,3 \pm 5,8$, $90,9 \pm 5,3 \%, \mathrm{n}=3$, соответственно, от сигналов, полученных при использовании свежеприготовленного препарата.

\section{Хранение планшета,}

активированного иммуноглобулином 14D5

Планшеты, подготовленные, как описано в «Материалах и методах», хранили при 8 либо минус $18{ }^{\circ} \mathrm{C}$. Периодически планшеты использовали для биолюминесцентного иммуноанализа контрольного образца К+. Показано, что поверхность планшетов не теряет способности иммобилизировать мишень: после 1, 3, 12 месяцев хранения величина сигнала составила 95,2 $\pm 3,43 \%(n=12)$ от сигнала при аналогичном анализе на свежеприготовленных планшетах.

\section{Биолюминесиентный}

иммуноанализ клещзей

В течение сезонов 2016 и 2017 гг. разработанный способ выявления ВКЭ был применен к исследованию природных клещей. Анализ проводили по составленному протоколу, в который помимо описанной процедуры (см. «Материалы и методы») входило описание порядка измерения сигналов и автоматической обработки результатов с помощью планшетного люминометра Mithras. В качестве критерия наличия вируса использовали значение дискриминационного фактора Д, равного отношению биолюминесцентного сигнала от образца к сигналу контрольного негативного образца (K-, набор D-1154, Вектор Бест, Россия). При значении Д $\geq 2$ образец считали положительным по ВКЭ (ПС), в остальных 
Таблица 2. Результаты биолюминесцентного выявления ВКЭ в природных клещах

Table 2. Bioluminescent detection of TBEV in native ticks

\begin{tabular}{|c|c|c|c|}
\hline Год & Д, ОС $/ \mathrm{K}^{-}$ & Д, ПС/К & $\mathrm{K}^{+} / \mathrm{K}^{-}$ \\
\hline \multirow{2}{*}{2016} & $1,15 \pm 0,3$ & $2,77 \pm 0,8$ & $5,2 \pm 1,3$ \\
$\mathrm{n}=487$ & $\mathrm{n}=15$ & $\mathrm{n}=9$ \\
\hline \multirow{2}{*}{2017} & $1,1 \pm 0,3$ & $5,3 \pm 1,1$ & $16,6 \pm 5,8$ \\
& $\mathrm{n}=414$ & $\mathrm{n}=4$ & 17 \\
\hline
\end{tabular}

случаях - отрицательным по ВКЭ (ОС). Результаты исследований приведены в табл. 2 . Все образцы параллельно были исследованы с помощью набора для колориметрического иммуноанализа, результаты которого принимали как истинные. Всего за этот период нами исследовано 920 образцов экстрактов клещей, из которых положительными оказались 19. Полученное по результатам двух сезонов значение чувствительности биолюминесцентного способа выявления ВКЭ составило 89,5 \%, т.е. два образца были ложноотрицательными, с пограничными значениями Д 1,98 и 1,86 . Специфичность анализа составила 98,9 \%, т.е. ложноположительными оказались 10 образцов. Возможно, этот результат связан с разницей в чувствительности колориметрического и биолюминесцентного способов анализа. К сожалению, ограниченный объем предоставленного материала не позволил провести дополнительный независимый анализ спорных образцов. Необходимо отметить, что значение дискриминационного фактора было выбрано из общих соображений и не исключено, что дополнительные исследования позволят уточнить его значение.

По сравнению с колориметрическим иммуноанализом ВКЭ в клещах предложенный биолюминесцентный способ характеризуется более высокой чувствительностью (о чем свидетельствуют эксперименты с лабораторными клещами (Burakova et al., 2015)) и уко- роченным временем анализа: в процедуре отсутствуют стадии добавления и инкубирования субстрата фермента, а также добавления стоп-реагента. По сравнению с анализом на основе ОТ-ПЦР метод существенно проще, поскольку не требует специального оборудования, ферментов и особых условий проведения анализа.

В тест-систему необходимым компонентом входит, как правило, инструментальная часть. В наших исследованиях биолюминесцентный сигнал репортера измеряли с использованием планшетного биолюминометра LB 940 Mithras (Berthold, Германия) исследовательского типа, обладающего целым рядом опций, необходимых для проведения научных работ. Это, безусловно, отражается на стоимости такого оборудования. В случае прибора, пригодного для рутинных исследований, такого разнообразия функций не требуется. В рамках данного исследования нами были сформулированы основные технические параметры люминометра для рутинных лабораторных исследований и разработана модель такого прибора, а также программное обеспечение к нему (Патент РФ, 2017). Отметим, что создание отечественного прибора подобного типа откроет возможность для применения биолюминесцентного анализа других важных для медицинской диагностики мишеней (см., напр., Frank, Krasitskaya, 2014). 


\section{Благодарности / Acknowledgements}

Исследование выполнено при финансовой поддержке Российского фонда фундаментальных исследований, Правительства Красноярского края, Красноярского краевого фонда поддержки научной и научно-технической деятельности в рамках научного проекта № 16-44-240648 p_a. Авторы благодарны сотрудникам Центра гигиены и эпидемиологии Красноярского края за предоставленные для исследований экстракты природных клещей.

The study was funded by the Russian Foundation for Basic Research, Government of Krasnoyarsk Territory, Krasnoyarsk Region Science and Technology Support Fund (project No. 16-44-240648) and the state budget allocated to the fundamental research at the Russian Academy of Sciences, project No. 0356-2016-0712. The authors are grateful to the staff of the Center for Hygiene and Epidemiology of Krasnoyarsk Region for providing extracts of the native ticks.

\section{Список литературы / References}

Байков И.К., Матвеев Л.Е., Матвеев А.Л., Тикунова Н.В. (2012) Сравнительный анализ вариабельных доменов моноклональных антител против вируса клещевого энцефалита. Сибирский медицинский журнал (Иркутск), 111(4): 30-33 [Baykov I.K., Matveev L.E., Matveev A.L., Tikunova N.V. (2012) Comparative analysis of variable domains of monoclonal antibodies against tickborn encephalitis virus. Siberian Medical Journal (Irkutsk) [Sibirskij Medicinskij Zurnal (Irkutsk)], 111(4): 30-33 (in Russian)]

Патент РФ (2014) № 2513686 [Patent RF (2014) No. 2513686 (in Russian)]

Патент РФ (2017) № 177777 [Patent RF (2017) No. 177777 (in Russian)]

Baykov I.K., Levanov L.N., Matveev L.E., Tikunova N.V. (2009) Development of the singlechain antibodies against tick-borne encephalitis virus. Proceedings of the conference "Genomics and proteomics in medicine". Novosibirsk, p. 98

Burakova L.P., Kudryavtsev A.N., Stepanyuk G.A., Baykov I.K., Morozova V.V., Tikunova N.V., Dubova M.A., Lyapustin V.N., Yakimenko V.V., Frank L.A. (2015) Bioluminescent detection probe for tick-borne encephalitis virus immunoassay. Analytical and Bioanalytical Chemistry, 407(18): 5417-5423

Frank L.A., Krasitskaya V.V. (2014) Application of enzyme bioluminescence for medical diagnostics. Advances in Biochemical Engineering/Biotechnology, 144: 175-197

Kudryavtsev A.N., Burakova L.P., Frank L.A. (2017) Bioluminescent detection of tick-borne encephalitis virus in native ticks. Analytical Methods, 9(15): 2252-2255

Lenhard T., Ott D., Jakob N.J., Pham M., Baumer P., Martinez-Torres F., Meyding-Lamade U. (2016) Predictors, neuroimaging characteristics and long-term outcome of severe european tick-borne encephalitis: a prospective cohort study. PLoS One, 11(4): e0154143

Stepanyuk G.A., Unch J., Malikova N.P., Markova S.V., Lee J., Vysotski E.S. (2010) Coelenterazine-v ligated to $\mathrm{Ca}^{2+}$-triggered coelenterazine-binding protein is a stable and efficient substrate of the redshifted mutant of Renilla muelleri luciferase. Analytical and Bioanalytical Chemistry, 398(4): 18091817

Stepanyuk G.A., Liu Z.J., Vysotski E.S., Lee J., Rose J.P., Wang B.C. (2009) Structure based mechanism of the $\mathrm{Ca}^{2+}$-induced release of coelenterazine from the Renilla binding protein. Proteins, 74(3): 583-593 
Süss J. (2011) Tick-borne encephalitis 2010: epidemiology, risk areas, and virus strains in Europe and Asia-an overview. Ticks and Tick-borne Diseases, 2(1): 2-15

Titushin M.S., Markova S.V., Frank L.A., Malikova N.P., Stepanyuk G.A., Lee J., Vysotski E.S. (2008) Coelenterazine-binding protein of Renilla muelleri: cDNA cloning, overexpression, and characterization as a substrate of luciferase. Photochemical \& Photobiological Sciences, 7(2): 189-196

Tsekhanovskaya N.A., Matveev L.E., Rubin S.G., Karavanov A.S., Pressman E.K. (1993) Epitope analysis of tick-borne encephalitis (TBE) complex viruses using monoclonal antibodies to envelope glycoprotein of TBE virus (persulcatus subtype). Virus Research, 30(1): 1-16 